\title{
Sistem Informasi Manajemen Riset \\ Berbasis Cyber pada Perguruan Tinggi
}

\section{Cyber-Based Research Management Information System in Higher Education}

\author{
Eka Prihatin \\ Administrasi Pendidikan, Universitas Pendidikan Indonesia, Bandung, Jawa Barat, Indonesia \\ ekaprihatin@upi.edu
}

Naskah diterima tanggal 19/02/2019, direvisi akhir tanggal 22/04/2019, disetujui tanggal 30/04/2019

\begin{abstract}
Abstrak
Memasuki era Revolusi Industri 4.0 yang di dominasi oleh teknologi dan sistem otomatisasi menjadi mega trend dunia yang merambah pada seluruh aspek kehidupan, demikian juga dengan pendidikan dimana manajemen perguruan tinggi di seluruh belahan dunia beradaptasi terhadap perubahan ini. Penelitian ini berkaitan dengan system informasi manajemen riset yang didominasi dengan cloud teknologi. Tujuan penelitian ini adalah untuk mengembangan suatu smart system yang didasarkan pada data hasil penelitian ketidakpuasan renponden terhadap sistem yang selama ini berjalan. Responden pada penelitian ini adalah tenaga pendidik sebagai peneliti, sedangkan teknik pengambilan data dalam penelitian ini dilakukan melalui kuesioner (online). Hasil penelitian ini berupa smart system yang berbasis cloud teknologi sebagai penyempurnaan dari sistem yang sedang berjalan. Kelebihan sistem ini adalah (1) kemudahan akses; (2) efektif dan efisien; (3) transparan; (4) objektif; (5) mengelola hasil penelitian.
\end{abstract}

Kata kunci: cyber riset, kepuasan, smart system.

\begin{abstract}
Entering the era of industrial revolution 4.0 which dominated automation technology and systems became the mega World trend that combines all aspects of life, as well as education where management of universities throughout the world is associated with this change. This study discusses the research management information system that addresses cloud technology. The purpose of this study is to develop intelligent systems that are based on satisfying research data on the system that has been running. Responding to this study were educators as researchers, while the data collection techniques in this study were conducted through questionnaires (online). The results of this study are smart systems that are cloudbased technology as improvements to the current system. The advantages of this system are (1) excess access; (2) effective and efficient; (3) transparent; (4) Objectives; (5) regulating the results of the study.
\end{abstract} Keywords: cyber research, satisfaction, smart systems.

\section{PENDAHULUAN}

Universitas Pendidikan Indonesia (UPI) sebagai salah satu universitas yang memiliki core business dalam bidang pendidikan dalam pelaksanaannya tidak akan terlepas dari Tridharma Perguruan Tinggi. Ketiga aspek yang diamanatkan dalam pelaksanaan bisnis pendidikan harus dikelola secara komprehensif dengan mengoptimalkan sumber daya yang dimilikinya. Ketiga aspek yang diemban dalam Tridharma Perguruan Tinggi saling berkaitan satu dengan yang 
lain tidak dapat dikaji secara parsial karena antara pendidikan, pelatihan dan pengabdian kepada masyarakat akan terus saling mengisi, melengkapi, menunjang dan mendorong pertumbuhan dan perkembangan institusi (Lubis, 2016). Pengelolaan secara professional dalam ketiga aspek tersebut akan mengoptimalkan mutu pembelajaran sehingga lulusannya memiliki tingkat kualitas yang mampu bersaing dengan lulusan Perguruan Tinggi lain dalam lingkup nasional maupun internasional.

Lembaga Penelitian dan Pengabdian Kepada Masyarakat sebagai lembaga yang mengelola 2 dari 3 dharma di Perguruan Tinggi (Sudin, 2004), menjadi lembaga yang sangat penting, sebagai dapur dari perguruan tinggi memerlukan pengelolaan secara professional serta visioner yang akan dijadikan data dan rujukan dalam setiap pengambilan keputusan, sehingga diperlukan sistem informasi manajemen riset yang mampu mengakomodir semua kebutuhan institusi (Andayani, 2010). Selain itu sistem informasi dibutuhkan untuk mengelola kegiatan-kegiatan penting, dan dapat memberikan akses informasi yang cepat (Wijaya, 2016).

Sistem informasi manajemen riset yang dimaksud adalah sebuah pengelolaan riset yang memakai kaidah dari fungsi-fungsi manajemen sehingga dengan manajemen riset maka semuanya tertata rapi yang akan memudahkan setiap yang berkepentingan untuk mengaksesnya (Susanto, Mantja, Bafadal, \& Sonhadji, 2017). Pengelolaan secara profesional dari mulai usulan penelitian dari dosen, sampai dengan proses seleksi yang bermarwah serta pengelolaan hasil penelitian yang diakhiri dengan analisis hasil penelitian, semuanya dilakukan melalui program sehingga memiliki tingkat akuntabilitas, reliabilitas dan equitable yang tinggi.

Jurnal Penelitian Pendidikan
Salah satu keluhan dari para pengusul penelitian menyatakan bahwa mengapa usulannya tidak diterima? salahnya dimana? dan alasannya apa? Melalui program manajemen riset ini maka tidak akan ada lagi keluhan dan prasangka yang akan merusak motivasi para peneliti untuk berhenti berkarya dan berhenti meneliti, karena perkembangan keilmuan berawal dari penelitian. Begitu pula dengan penelitian yang akan didanai, jangan sampai ada judul penelitian yang tidak sesuai dengan fokus kajian yang ada dalam rencana strategis penelitian Perguruan Tinggi, karena hal tersebut menjadi pemborosan bagi institusi.

Hasil penelitian yang sebenarnya dapat dijadikan data dan bahan rujukan bagi masyarakat pendidikan hanya menjadi arsip, sehingga nilai kegunaannya berkurang dan tidak berdampak positif pada pertumbuhan dan perkembangan institusi, hal tersebut karena analisis hasil penelitian belum dapat diolah menjadi produk universitas yang dapat memberikan manfaat bagi institusi. Kontroling dari institusi sangat longgar karena data yang banyak dan tersebar serta acak-acakan akan menyulitkan dan memakan waktu yang lama, maka dengan program manajemen riset ini institusi dapat mengkaji, memahami dan mengontrol serta menganalisis hasil penelitian secara sederhana dan cepat.

Menghilangkan peluang pendapatan, seperti kasus tahun kemarin, dikti membuka bantuan dana penelitian dan jaringan indutri serta pendampingan usaha Perguruan Tinggi, Universitas pendidikna Indonesia tidak dapat memenuhinya karena informasinya terlambat, hasil penelitian yang akan diajukan tidak ditemukan karena lembaga tidak memiliki informasi hasil penelitian yang dapat dijadikan benefit bagi institusi. Kehilangan kesempatan tersebut mendorong peneliti untuk mendesain program manajemen 
riset berbasis komputerisasi yang akan memudahkan segalanya dan menghilangkan pemborosan karena UPI harus menegelola keuangan sendiri dengan status PTNbh.

\section{Konsep Sistem Informasi Manajemen Riset}

Research merupakan suatu kegiatan yang memerlukan perencanaan secara komprehensif sehingga pelaksanaannya memerlukan penanganan yang lebih serius dan tepat. Hasil dari penelitian merupakan hasil karya agung dapat berupa inovasi, metode atau cara penyelesaian yang paling tepat dalam menyelesaikan permasalahan. Nilai atas hasil penelitian dapat saja dalam kriteria efektivitas, dapat pula dalam kriteria efesiensi, atau kriteria yang bersifat universalitas yang dapat diberlakukan secara umum dan bisa mungkin hanya berlaku secara kasuistik.

Pengelompokan kriteri hasil akan memudahkan pengguna hasil penelitian untuk mengakses informasi yang dibutuhkan, sehingga hasil penelitian memiliki nilai manfaat yang optimal. Demikian juga temuan-temuan dalam hasil penelitian dapat menjadi peluang bagi pengguna untuk mengembangkannya dalam unit bisnis sehingga dapat menjadi sumber dana bagi institusi. Optimalisasi kegunaan penelitian ini dapat dikendalikan dan diberi ruang dengan melakukan pengelolaan secara professional dari mulai perencanaan tema dan kajian yang dibutuhkan oleh institusi, hal untuk memperkecil peluang pemborosan dalam sumber dana.

Penatalaksanaan maupun pengelolaan mengandung makna yang hampir sama yang lebih popular dengan kata manajemen, dimana penatalaksanaan memberikan makna adanya upaya penyusunan kegiatan agar tercipta keteraturan dan pengaturan sehingga tercapai efektifitas dan efesiensi yang diharapkan, sedangkan pengelolaan mengandung makna penyelenggeraan kegiatan yang secara fungsional dilakukan dan yang berlangsung sistematis guna mencapai tujuan secara efektif efesien.

1. Manajemen sebagai suatu sistem (management as a system) berarti manajeman adalah suatu kerangka kerja yang terdiri dari berbagai bagian yang secara keseluruhan saling berkaitan yang dikoordinasikan sedemikain rupa dalam rangka pencapaian tujuan organisasi.

Sebagai kerangka kerja memberikan petunjuk bahwa manajemen adalah suatu pekerjaan yang dilakukan dalam satu kesatuan kegiatan yang dalam dinamikanya berlangsung sebagai suatu proses sedangkan dalam statistikanya tersusun secara fungsional. Sebagai suatu proses maka kegiatan itu terjadi dari suatu titik tertentu dan akan berakhir pada suatu titik yang tidak akan diketahui akhirnya. Sedangkan dalam suatu susunan fungsional maka dimaksudkan adalah bahwa kegiatan tersusun atas dasar kegiatan yang sama dan satu tujuan sehingga dapat dikenali ada sekelompok kegiatan yang menyerap banyak waktu dan tenaga oleh kegiatan berpikir, ada yang menyerap secara seimbang antara pikiran dan tindakan fisik, dan ada yang menyerap terbanyak waktu dan tenaga atas pikiran dan tindakan yang dilakukan.

Baik sebagai proses maupun sebagai susunan, keduanya berlangsung secara terorganisir. Keduanya berada dalam suatu bentuk kerjasama manusia dengan peralatan yang digunakan secara rasional guna pencapaian efektifitas dan efesiensi. Efektivitas adalah nilai ketepatan, nilai kesesuaian yang dihasilkan sedangkan efesiensi adalah nilai guna dan kemanfaatan yang diharapkan tercapai.

2. Manajemen sebagai suatu ilmu pengetahuan (management as a science) yang berarti bahwa manajemen adalah Jurnal Penelitian Pendidikan 
suatu ilmu yang bersifat interdisipliner dengan menggunakan bantuan ilmu-ilmu sosial, filsafat dan matematika.

Sebagaiilmupengetahuan, manajemen memiliki obyek material dan obyek formal. Obyek materialnya adalah manusia dengan kegiatan-kegiatan dalam pencapaian tujuan sedangkan obyek formal adalah penggunaan kegiatan dan pemikiran orang dengan bantuan ilmu-ilmu lain seperti sosiologi, ekonomi, antropologi, psikologi, politik, filsafat dan matematika statistika. Posisi demikian itu menjadikan manajemen dalam tertib keilmuan dapat digolongkan sebagai ilmu interdisiplin. Ia dapat dipelajari sebagai suatu ilmu pengetahuan yang menjadikan seseorang dapat memiliki kompetensi dan profesional dibidang manajemen.

3. Sebagai suatu profesi (management as a profession) akan berarti bahwa manajemen mempunyai bidang pekerjaan atau bidang keahlian yang tertentu, seperti bidang-bidang lainnya.

Kegiatan-kegiatan yang berlangsung baik dalam proses maupun dalam susunan secara fungsional melahirkan teori fungsi. Teori fungsi manajemen adalah teori hasil kajian atas konsep fungsi sebagai satuan kelompok kegiatan dan tujuan yang sama, dalam pengertian bahwa kegiatan dan tujuan yang sama dikelompokan dalam satu kesatuan fungsi.

Manajemen secara konseptual adalah kegiatan yang dilakukan untuk mencapai tujuan dengan menggunakan cara dan pemikiran orang lain (Pangestika, 2018). Jika kegiatan-kegiatan manajemen itu dibagi kedalam satuan-satuan fungsi, maka inilah yang dimaksudkan dengan teori fungsi manajemen. Pengelompokkan kegiatan kedalam fungsi didasarkan pada pendekatan-pendekatan tertentu sehingga hasilnya melahirkan teori fungsi yang berbeda-beda, ada yang membagi fungsi

Jurnal Penelitian Pendidikan itu kedalam 7 fungsi yang di konsepsikan sebagai "POSDCORB" oleh Gullick, ada yang membagi kedalam 6, 5, 4 fungsi, malah ada yang membaginya kedalam 2 fungsi utama yaitu organik manajemen dan dinamik manajemen (Rokhayati, 2014).

Fungsi manajemen adalah sebagai hasil kajian berdasarkan pendekatan yang dilakukan oleh pemilik kompetensi di bidang manajemen maka akan memiliki kompetensi di bidang ilmu administrasi (Arif, 2012). Oleh karena itu, yang perlu ditegaskan bahwa pencapaian tujuan dengan cara dan pemikiran orang lain adalah sesuatu kekuatan yang mendasari kegiatan yang berlangsung, baik itu kekuatan yang melandasi kegiatan yang berkenaan pemikiran maupun yang berkaitan dengan kekuatan yang melandasi kegiatan yang menyerap tenaga fisik manusia dan yang bersentuhan dengan dua kekuatan atas kegiatan yang dilaksanakan.

Kekuatan yang berkenaan dengan kegiatan pemikiran yang menyerap energi akal manusia digolongkan pada fungsi perencanaan, sedangkan yang berkaitan dengan tenaga fisik manusia digolongkan pada fungsi pelaksanaan. Sedangkan yang bersentuhan dengan dua kekuatan yang digunakan adalah digolongkan pada fungsi pengawasan. Ketiga fungsi inilah yang digunakan didalam mengelola organisasi, didalam melakukan penatalaksanaan organisasi.

Secara konseptual, perencanaan adalah suatu ikhtiar untuk menjamin agar setiap usaha kerja sama berhasil dengan sukses. Bukan saja "apa" yang harus diperbuat, melainkan "bagaimana", "dimana", "kapan", oleh "siapa" segala sesuatu itu harus dilaksanakan. Rumusan lainnnya, banyak ditemukan dalam berbagai literatur, seperti rumusan menyatakan bahwa perencanaan dalam arti seluas-luasnya tidak lain adalah suatu proses mempersiapkan secara sistematis kegiatan-kegiatan yang akan 
dilakukan untuk mencapai suatu tujuan tertentu.

Pelaksanaan sebagai satu kesatuan kegiatan adalah dimaksudkan sebagai fungsi yang akan melaksanakan apa yang direncanakan guna mencapai tujuan yang dikehendaki oleh organisasi. Didalam pengelolaan kegiatan pelaksanaan, banyak kegiatan yang harus dilakukan secara nyata, kegiatan yang berwujud tindak lanjut secara konkrit dari apa yang diinginkan dalam perencanaan.

Pengawasan adalah fungsi untuk mengetahui kesesuaian yang terjadi dari apa yang diinginkan dengan apa yang terjadi (Baihaqi, 2016). Konsepsi pengawasan banyak dikemukakan para ahli lewat literatur baik yang berkenaan dengan manajemen sebagai studi maupun secara khusus pada pengawasan sebagai studi yang dipelajari berdiri sendiri.

\section{Cyber Research University}

Berdasarkan arti cyber dimaksudkan sebagai dunia maya, internet atau cloud technology, sehingga cyber research university adalah pengelolaan riset universitas menggunakan cloud technology. Hal tersebut sebagai bentuk adaptasi UPI terhadap megatrend revolusi industry 4.0. Era ini didominasi dengan teknologi dan system otomasi, tujuannya adalah memberikan kemudahan dan kepuasan kepada customer.

$$
\text { Cyber research university }
$$
diaplikasikan pada smart system yang mengelola penelitian, dimulai dari penerimaan proposal sampai pengelolaan hasil penelitian. Semua kegiatannya berbasis teknologi dan konektifitas (internet of thing). Manfaat smart system ini akan memberikan kemudahan dan sistem otomatisasi sehingga efektif dan efisien, transparan, objektif, memiliki adaptabilitas yang tinggi pada perubahan dalam era revolusi industri.

Konsep penelitian yang menyusung tema mengenai pengembangan sistem informasi manajemen telah banyak diteliti, salah satunya adalah oleh (Taryono, 2018); (Al Ghofari, Anis, \& Nugroho, 2014; Sasongko, 2009); (Aswati, Mulyani, Siagian, \& Syah, 2015; Faqih \& Informasi, 2005; Maryawan, Sumadi, \& Suntoro, 2013; Susanto et al., 2017; Wiguna, 2017).

\section{METODE PENELITIAN}

Penelitian ini merupakan penelitian dan pengembangan (Research \& Development) yang merupakan perbatasan dari pendekatan kualitatif dan kuantitatif, dan terutama untuk menjembatani kesenjangan antara penelitian dan praktek pengelolaan merupakan penelitian terapan, yang lebih mementingkan perubahan untuk perbaikan (what works better), dari pada kemengapaan (why) (Sugiyono, 2016). Pendekatan kuantitatif dilakukan untuk mendapatkan data dan informasi terkait dengan tingkat kepuasan responden terhadap (1) Tingkat kepuasan responden terhadap system informasi riset UPI; (2) Tingkat kepuasan responden terhadap proses sistem informasi riset UPI yang selama ini digunakan; dan (3) Tingkat kepuasan responden terhadap hasil keputusan riset UPI.

Teknik wawancara yang dilakukan adalah wawancara terstruktur, teknik pengambilan sampel melalui purposive sampling yaitu pengambilan sampel sumber data dengan pertimbangan (1) responden yang sering mendapatkan proposalnya layak untuk di danai; (2) responden yang kadang-kadang proposal penelitiannya layak untuk didanai; dan (3) adalah responden yang proposal penelitiannya jarang layak didanai. Hasil data dan informasi tersebut menjadi dasar dalam pengembangan SIM riset yang digunakan, dipadukan dengan era Revolusi Industri 4.0 yang dikuasai dengan teknologi dan otomasi melalui cloud teknologi berupa smart system. Smart system ini memiliki 6 tahap pengembangan yang diikuti dengan ujicoba terbatas dan ujicoba luas. Analisis hasil ujicoba bertujuan untuk menyempurnakan smart system. 


\section{HASIL DAN PEMBAHASAN}

\subsection{Hasil}

\section{Kepuasan Responden Terhadap Sistem} Informasi Riset Saat Ini

Kepuasan responden (Dosen atau peneliti) terhadap sistem informasi riset yang sekarang memang tidak terlalu menggembirakan, dimana dari kuesioner penelitian yang disebarkan dengan menggunakan online sistem cukup representative dibanding dengan jumlah keseluruhan dosen.

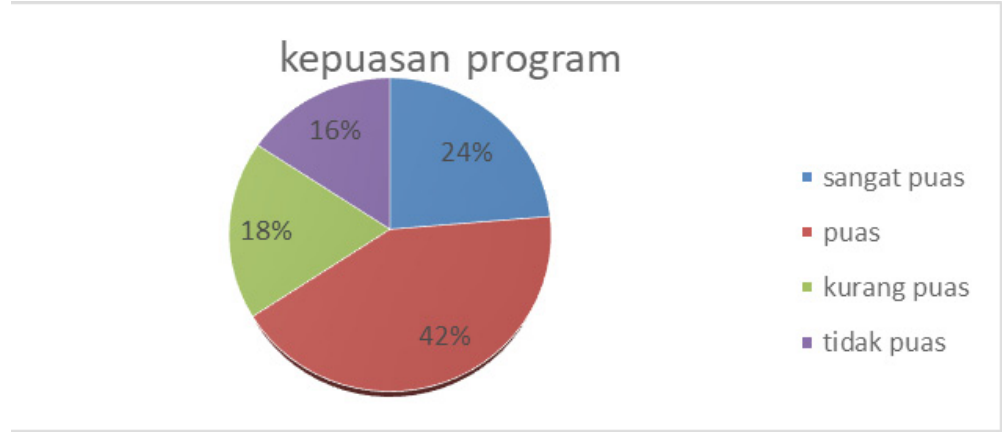

Gambar 1. Hasil Kepuasan pada Program

Data pada gambar 1 menunjukkan bahwa dari 250 responden yang memberikan respon menunjukkan bahwa ada

1. $24 \%$ responden yang mengatakan sangat puas, bahwa dengan kemudahan menggunakan online system dan sistem otomatisasi yang akan menjadi peringatan jika ada kesalahan maupun kekurangan dalam proses penelitian.

2. $42 \%$ responden yang menyatakan puas bahwa sistem tersebut memudahkan bagi peneliti dan sistem otomatisasi sebagai peringatan untuk segera dilengkapi.

3. Responden yang menyatakan kurang puas sebesar $18 \%$, hal tersebut berkaitan dengan keluhan bahwa sistem mengunci sehingga peneliti tidak bisa meng-upload pengusulan proposalnya, dan juga sistem selalu terganggu jika hari terakhir batas pengusulan dan pelaporan.

4. Responden yang tidak puas terhadap sistem tersebut sebesar $16 \%$, karena sering terganggunya sistem akibat overload ataupun akibat lainnya yang menjadi kerugian bagi pengusul karena tidak dapat mengusulkan sesuai dengan batas waktu yang ditentukan
Dari data hasil penelitian di atas ada menunjukkan bahwa ada 34\% responden yang menjadi pengusul penelitian yang menyatakan ketidakpuasan dengan system informasi riset UPI yang selama ini dilakukan berdasarkan tingkat kemudahan proses maupun akses. Hambatan dalam tingkat kesulitan proses dapat diselesaikan dengan menyempurnakan SIM riset yang berbasis pada kemudahan penggunaannya. Alasan re-desain SIM ini adalah agar peneliti sebagai kantemer internal merasakan kepuasan dalam meneliti sehingga akan lebih termotivasi lagi untuk melakukan penelitian, selain itu penelitian merupakan salah satu tridharma yang harus/wajib dilakukan oleh tenaga pendidik perguruan tinggi. Selain itu hasil penelitian dapat bermanfaat bagi pendapatan dan pertumbuhan universitas. Hasil penelitian yang bisa dijadikan dan dikembangkan menjadi usaha universitas akan meningkatkan pendapat, sedangkan setiap luaran penelitian yang akan dipublikan baik pada seminar nasional maupun internasional serta terpublikasikan pada jurnal nasional dan internasional yang bereputasi akan meningkatkan rangking 
dunia universitas.

Sedangkan responden yang menyatakan puas dengan sistem informasi riset yang selama ini dilakukan 66\% merupakan peneliti yang aktif, sehingga perlu untuk dipertahankan bahkan untuk dikembangkan dengan lebih meningkatkan kepuasan penelitiuntuk mendapatkan manfaat yang lebih pula untuk pengembangan usaha dan pertumbuhan universitas. Dengan re- desain SIM riset ini maka akan meningkatkan kepuasan peneliti baik yang aktif maupun yang belum aktif, sehingga penelitian akan menjadi kewajiban dan budaya universitas.

Tingkat Kepuasan Responden Terhadap Proses Sistem Informasi Riset yang Digunakan.

Data hasil penelitian berkaitan dengan alur proses sistem yang digunakan dalam manajemen penelitian adalah sebagai berikut:

\section{Chart Area \\ - sangat puas - puas = kurang puas " tidak puas}

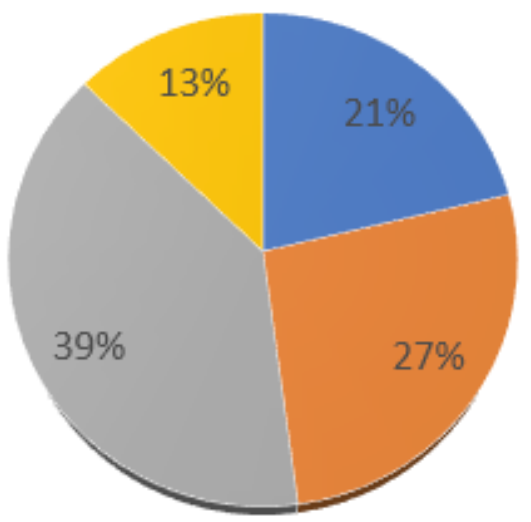

Gambar 2. Tingkat Kepuasan pada Sistem Informasi Riset

Data pada gambar 2 hasil penelitian menunjukkan bahwa

1. $21 \%$ responden menyatakan sangat puas, bahwa alur manajemen proposal sudah sangat baik

2. $27 \%$ responden menyatakan puas mengenai alur proses manajemen proposal yang dipakai UPI cukup memuaskan

3. 39\% responden menyatakan kurang puas karena kegiatan alur proses manajemen riset yang seharusnya sederhana akan tetapi menjadi sebuah kegiatan yang menghabiskan banyak waktu dan biaya, selain itu kegiatan evaluasi presentasi proposal dipertanyakan keobjektifan penilaiannya

4. $13 \%$ menyatakan tidak puas, dengan alasan alur SIM riset ini terlalu bertele- tele dan menghabiskan banyak sumber daya dari mulai manusia, biaya, waktu, dan tempat, lalu dipertanyakan pemilihan reviwer berdasarkan apa, transparansi penilaian, objektifivitas reviwer, tidak adanya umpan balik proposal yang ditolak sehingga pengusul tidak mengetahui kekurangannya.

Adapun $48 \%$ responden menyatakan puas dengan alur SIM yang selama ini dipergunakan, menjadi satu kelebihan dan kesempatan untuk lebih meningkatkan lagi kualitas SIM riset yang dilaksanakan, hal tersebut untuk meningkatkan kepuasan dosen/ peneliti dalam menggunakan Sim riset ini, diharapkan dapat meningkatkan kebutuhan untuk meneliti sehingga inovasi hasil riset dapat memberikan kontribusi terhadap 
pendapatan dan pertumbuhan universitas melalui usaha hasil inovasi riset dan lebih banyak dan berkualitasnya publikasi baik melalui konferensi nasional dan internasional maupun publikasi pada jurnal nasional dan internasional yang bereputasi.

Dan ada $52 \%$ yang menyatakan tidak puas terhadap alur proses manajemen riset yang selama ini digunakan, hal tersebut akan menjadi kerugian yang besar, karena $52 \%$ penbeliti memilih untuk tidak melakukan penelitian karena merasa bahwa proses SIM riset ini tidak memuaskan, sehingga menurunkan motivasi untuk meneliti. Ketidak puasan ini berkaitan dengan SIM yang dirasakan sangat ribet dan hambatan dalam akses program. Solusinya adalah dengan membuat desain SIM yang memberikan kemudahan dalam proses dan dalam akses program sehingga SIM riset bukan menjadi penghalang keaktifan dosen dalam melakukan penelitian. Dalam mengelola 52\% peneliti ini adalah dengan meningkatkan motivasi meneliti melalui solusi dari analisis kegagalan program/ alur SIM riset yang selama ini digunakan.

Tingkat Kepuasan Responden Terhadap Hasil Keputusan Penerima Dana Penelitian

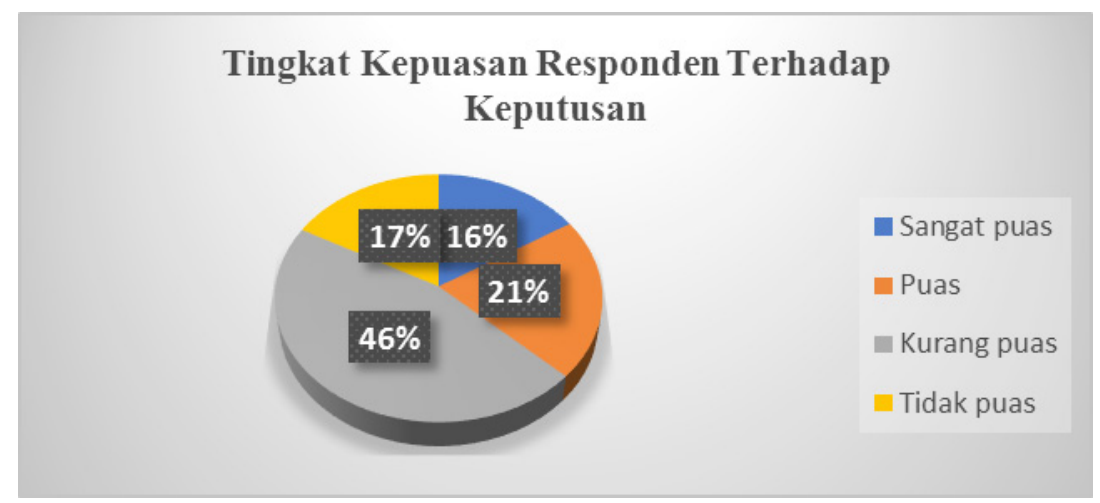

Gambar 3. Tingkat Kepuasan Responden Terhadap Keputusan

Tingkat kepuasan responden pada gambar 3 terhadap hasil keputusan penerima dana penelitian sangat rendah, karena hanya $33 \%$ yang menyatakan puas dan selebihnya yaitu 67\% menyatakan kurang puas atas putusan penerima dana penelitian. Alasan ketidakpuasan adalah penilaian kelayakan proposal yang diterima tidak diketahui standarnya, selain itu penilaian berdasarkan skor yang diberikan oleh reviwer, responden mempertanyakan keobjektifan skor yang diberikan. Satu alasan lagi yang dikemukakan bahwa proposal yang tidak memiliki kelayakan di danai tidak diberikan feedback tentang kekuranglayakan proposal tersebut, sehingga pengusul tidak mengetahui kekurangan dari proposal tersebut.
Disini diperlukan sebuah system yang menghilangkan sifat subjektifitas penilayan kelayakan proposal dan diperlukan standar baku penilaian yang menjadi guideline penilaiannya dan transparansi hasil penilaian sehingga pengusul yang proposalnya tidak lolos untuk di danai dapat melakukan evaluasdi kekurangan proposal tersebut

Untuk menegaskan hasil kuesioner maka dilakukan wawancara terstruktur. Hasil wawancara yang dilakukan kepada pengusul yang usulannya diterima terkait dengan bagaimana sistem alur simlitabmas yang sekarang digunakan, hasilnya hamper semua menyatakan cukup bagus namun ada beberapa yang kurang yaitu pemilihan reviwer setiap tahunnya itu-itu saja, kemudian 
dipertanyakan kriteria untuk menjadi reviwer dan siapa yang memilihnya. Jika LPPM, siapa yang berwenang untuk menentukan pilihan, apa standar yang dipakai untuk memilih reviwer tersebut dan yang lainnya

Hasil wawancara yang dilakukan kepada responden yang kadang mendapat penelitian dan kadang tidak dapat penelitian dengan pertanyaan yang sama mengemukakan bahwa harusnya usulan yang ditolak itu ada alasannya, dalam arti keterbukaan dari sistem ini tidak ada sama sekali, jadi tidak bisa untuk melakukan evaluasi diri terkait kenapa usulannya ditolak.

Hasil wawancara dengan responden yang tidak pernah lolos penelitiannya, dengan menggunakan pertanyaan yang sama, maka hampir semua jawabannya adalah kebingunagan apa kesalahan dari proposal yang diajukan sehingga di tolak, dan mereka merasa malas dan berpikiran bahwa percuma saja mengusulkan, karena pasti di tolak lagi.

\subsection{Pembahasan}

\section{Pengembangan SIM riset menjadi cyber research university}

SIM riset dibagi menjadi 4 kegiatan besar yaitu (1) pengusulan proposal; (2) proses pengelolaan proposal; (3) proses penilaian dan komunikasi keputusan; (4) manajemen hasil riset.

1. Pengusulan proposal, dimana selama ini pengusul memiliki 2 kegiatan yaitu melakukan print out proposal untuk mendapatkan pengesahan dari dekan atau direktur dan dari ketua LPPM, kegiatan yang lainnya adalah file proposal dengan scan pengesahan di upload di sistem yang digunakan (siblitabmas). Dalam hasil penelitian ini, peneliti mengembangkan desain sIstem yang memberikan kemudahan bagi pengusul penelitian yaitu melalui smart system.

Smart system ini merubah pola lama yaitu print out untuk pengesahan menjadi pengesahan yang otomatis dan langsung dilakukan oleh Dekan, Direktur dan ketua LPPM dengan cara membuka lembaran SIAK dan membuka plot menyetujui proposal yang diajukan dengan cara klik ceklis jika setuju dengan usulan proposal tersebut, konsep dasarnya sama persis dengan kinerja pengusulan mata kuliah yang dikontrak dan ijin ujian akhir. Proposal yang sudah terkumpul dalam big data diperiksa langsung oleh smart system berdasarkan payung penelitian yang telah ditetapkan oleh LPPM, dengan demikian eliminasi proposal sudah dilakukan berdasarkan standar payung penelitian. Seperti gambar 4 berikut ini:

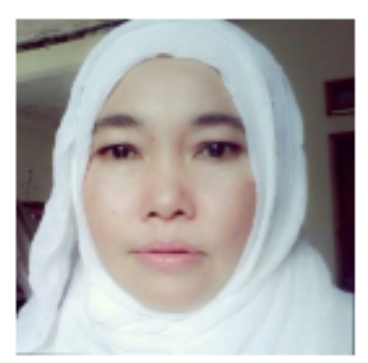

Peneliti

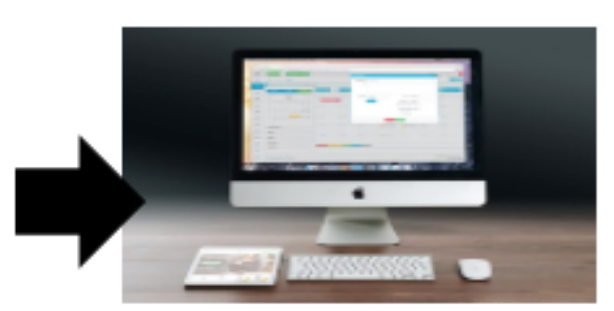

Upload proposal

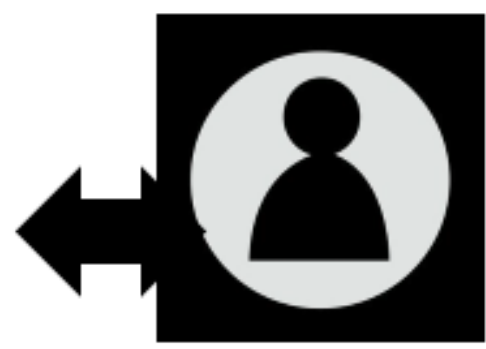

Dekan/Direktur/Ketua

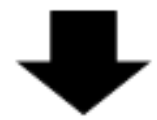

Proposal yang lolos tahap 1: sesuai dengan payung penelitian

Gambar 4. Alur smart system 
2. Manajemen Reviewer, standar reviewer bisa berdasarkan keaktifan penelitian, jabatan fungsional, atau banyaknya publikasi ilmiah. Pola lama menunjukkan bahwa reviewer dipilih oleh LPPM berdasarkan standar tertentu, sehingga setiap tahun yang menjadi reviewer adalah orang yang sama, biasanya salah satu standarnya adalah telah mengikuti TOT reviewer. Pola lama tersebut untuk memasuki era IR 4.0 sudah tidak lagi dipergunakan akan tetapi beralih pada standar yang telah disebutkan di atas, dengan asumsi bahwa semua peneliti layak menjadi reviewer penelitian, sehingga desain standar reviewer adalah sebagai berikut:

a. Setiap peneliti memiliki kesempatan yang sama untuk menjadi reviewer (terlepas dari keikutsertaan workshop reviewer) seperti pada gambar 5 . LPPM menentukan standar reviewer dan smart system mengacak big data (semua peneliti) dan memunculkan kandidat yang telah memenuhi standar yang mewakili setiap bidang keahlian di departemen atau prodi berbasis multi kompetensi. Ketika sudah terpilin maka smart system langsung mengirim surat persetujuan untuk menjadi reviewer dengan cara ceklis kata setuju
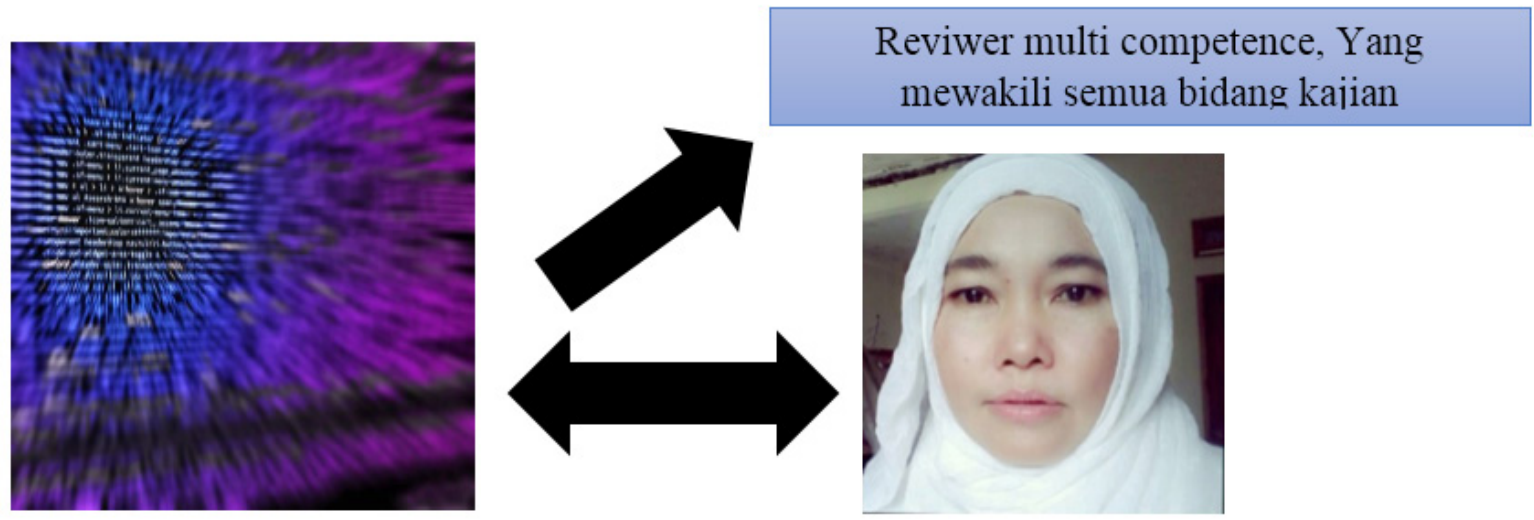

Gambar 5. Alur reviewer

b. Reviewer mereview proposal (yang lolos tahap 1) sesuai dengan bidang keahlian (yang telah disebutkan pada surat tugas) dimana smart system mengirim proposal tanpa tanda pengenal (nama, surel) dengan panduan penilaian yang telah ditetapkan seperti pada gambar 6. Reviewer memberikan penilaian berikut alasannya. Dan Proposal yang telah dinilai diberikan lagi kepada reviewer berbeda yang memiliki bidang keahlian yang sama untuk dievaluasi dan diberikan penilaian dengan alasannya.
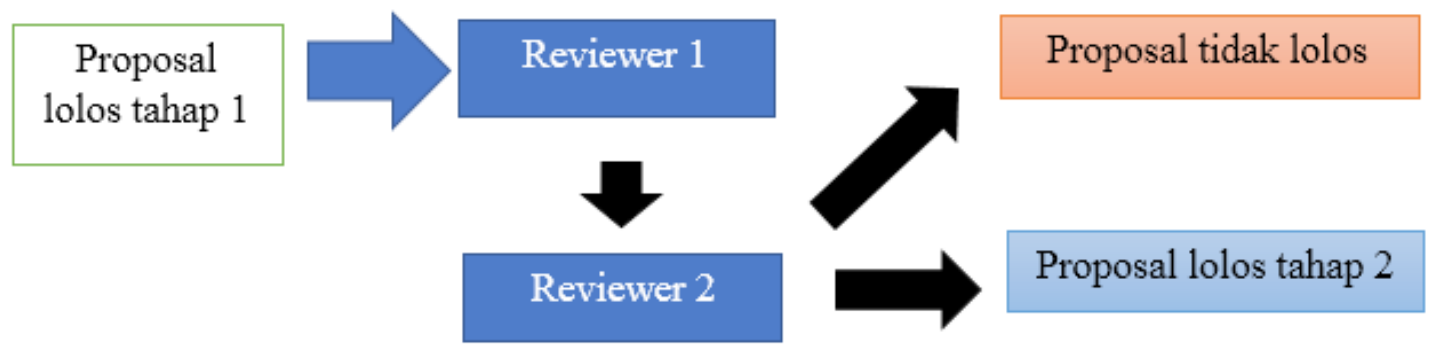

Gambar 6. Alur proses reviewer proposal 
c. Proposal yang lolos tahap 2 pada gambar 7 masuk pada penilaian selanjutnya yaitu penilaian akhir yang dilakukan oleh smart system berdasarkan kuota penelitian tiap skema berdasarkan nilai tertinggi. Proposal yang lolos tahap 3 dikirim pada ketua LPPM untuk persetujuan.
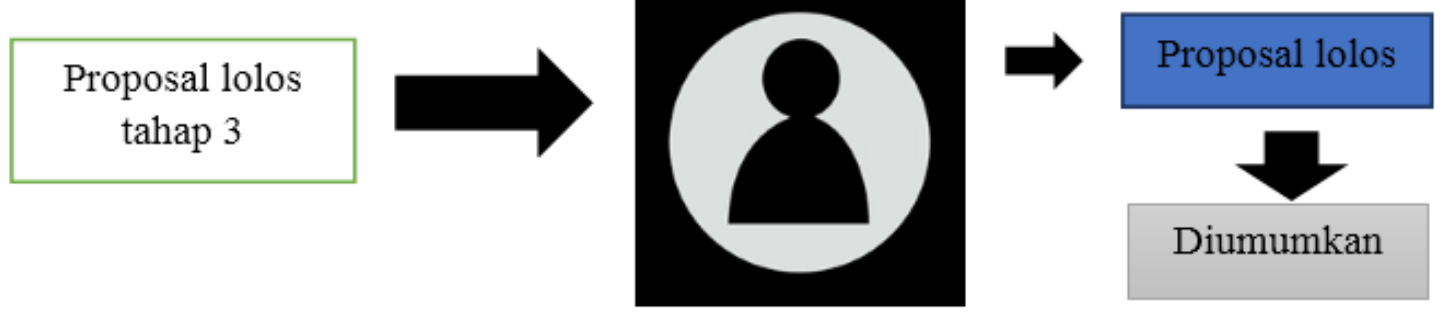

Gambar 7. Penilaian lanjutan

d. Proposal yang layak didanai mendapatkan SK elektronik yaitu Surat Perjanjian Pelaksanaan Program Hibah Penelitian dan Pengabdian Kepada Masyarakat di lingkungan Universitas Pendidikan Indonesia Tahun Anggaran antara Ketua LPPM UPI dengan Ketua peneliti. Dan penandatangannan juga bersifat elektronik (digital signature) dilakukan oleh Ketua LPPM dan Ketua Peneliti.

3. Proses penilaian dan komunikasi keputusan

Seperti telah dikemukakan di atas, maka penilaian setiap tahap harus disertakan alasan dari nilai tersebut sebagai feedback bahan evaluasi diri pengusul, dikomunikan langsung setiap tahap untuk setiap proposal yang tereliminasi. Didalam dilampirkan penilaian dan alasan dari nilai tersebut. Komunikasi keputusan bersifat transparan.

\section{Manajemen Hasil Riset}

Penelitian yang sudah selesai memiliki alur yang sama dengan pengusulan, dimana proposal yang telah selesai di upload dan lembar pengesahan dilakukan seperti lembar pengesahan proposal. Demikian juga dengan luaran penelitian yang telah dijanjikan harus di upload, masih sama dengan SIM yang biasa dilakukan laporan kegiatan, laporan keuangan, laporan akhir, artikel dan luaran yang lainnya yang sudah disepakati. Hasil penelitian akan dikelola oleh tim khusus setelah smart system dikelompokkan pada (1) pengembangan ilmu pengetahuan; (2) model pengembangan; (3) produk terapan; (4) inovasi produk; (5) usaha.

Divisi Pengembangan Ilmu Pengetahuan akan mengevaluasi dan menganalisis hasil penelitian yang akan mengembangkan kajian berbagai ilmu pengetahuan, kemudian ditindaklanjuti lebih mendalam melalui diskusi multi disiplin untuk mematangkan hasil penelitian menjadi teori yang akan dipublikasikan melalui berbagai conference dan jurnal nasional maupun internasional yang bereputasi, dan melalui buku. Semua media pemasaran teori baru dipergunakan untuk memberikan kemaslahatan pada masyarakat. Yang termasuk dalam pengembangan ilmu pengetahuan adalah (1) ilmu pengetahuan murni yang pengembangannya hanya berkaitan dengan ilmu tersebut; (2) ilmu pengetahuan berdasarkan irisan dari dua atau lebih ilmu pengetahuan; (3) ilmu pengetahuan yang merupakan gabungan dari dua atau lebih disiplin ilmu; (4) pengembangan ilmu pengetahuan yang menjadi embrio munculnya disiplin ilmu baru.

Divisi model pengembangan, adalah semua model baik yang representative maupun model yang sudah siap pakai dari semua disiplin ilmu. Divisi ini akan melakukan penilaian dan analisis keberhasilan setiap program dan kemudian dipasarkan melalui berbagai media diantaranya konferensi dan jurnal nasional dan internasional untuk dipasarkan dalam bentuk pelatihan dan pendampingan.

Devisi produk terapan adalah divisi yang menangani hasil penelitian yang merupakan 
produk yang bisa diterapkan. Setelah melalui pengembangan, evaluasi dan analisi serta ujicoba optimalisasi kualitas produk maka akan dipasarkan oleh institusi melalui konferensi dan jurnal baik nasional maupun internasional, buku, pelatihan dan pendampingan. Jika produk terapan yang disempurnakan dapat dipasarkan secara masal maka produk tersebut masuk pada divisi usaha yaitu bagian produksi untuk di perbanyak dan dipasarkan.

Divisi inovasi produk, divisi ini menangani inovasi dari produk yang telah ada atau adanya produk baru. Penyempurnaan, pengembangan dan analisis produk serta ujicoba produk menjadi faktor penting sebelum produk masuk pada divisi usaha untuk diproduksi secara masal dan dipasarkan kepada masyarakat.

Divisi usaha merupakan divisi yang menjadi bagian manajemen usala dari mulai produksi sampai dengan pemasaran dan standar control produk, pada divisi ini mengemban juga jaminan kualitas sehingga standar kualitas barang atau jasa tetap terjaga. Seperti dikemukakan di atas devisi usaha harus memiliki kompetensi dalam bidang pemasaran sehingga semua produk hasil penelitian baik itu pengembangan ilmu pengetahuan, pengembangan model, produk tetrapan, inovasi produk setelah layak jual masuk pada divisi ini. Tugas utama divisi ini menjual produk hasil penelitian dengan menggunakan berbagai strategi pemasaran yang tepat, sehingga semua hasil penelitian memberikan kontribusi positif terhadap universitas baik dalam peningkatan pendapatan universitas maupun meningkatkan kepercayaan dan marwah universitas berbasis pada kemaslahatan orang banyak. Adapun perbandingan sistem informasi manajemen SIM riset LPPM dengan SIM riset pengembangan seperti pada tabel 1 berikut.

\section{Tabel 1. Perbandingan Sistem Informasi Manajemen}

\begin{tabular}{|c|c|c|}
\hline No & SIM RISET LPPM & SIM RISET PENGEMBANGAN \\
\hline 1 & $\begin{array}{l}\text { Lembar pengasahan harus diprint kemudian } \\
\text { disahkan oleh Dekan/Direktur dan Ketua LPPM }\end{array}$ & $\begin{array}{l}\text { Dekan/ Direktur dan Ketua LPPM tinggal membuka Siak pada } \\
\text { plot pengesahan untuk menyatakan setuju atau tidak setuju2 }\end{array}$ \\
\hline 2 & Verifikasi proposal oleh LPPM & Verifikasi proposal oleh smart system \\
\hline 3 & Floting reviewer (review tahap 1) oleh LPPM & $\begin{array}{l}\text { Floting reviewer dilakukan oleh smart system dari big data } \\
\text { sesuai standar yang ditetapkan }\end{array}$ \\
\hline 4 & $\begin{array}{l}\text { Review tahap 1: proposal dikirim pada reviewer } \\
\text { lengkap dengan nama dan surel }\end{array}$ & $\begin{array}{l}\text { Review tahap 1: proposal dikirim via email tanpa nama dan } \\
\text { surel dan penilaian disertai alasannya }\end{array}$ \\
\hline 5 & Pengumuman review tahap 1 & $\begin{array}{l}\text { Proposal yang tereliminasi dikirim ulang dengan nilai dan } \\
\text { alasan dari nilai tersebut }\end{array}$ \\
\hline 6 & Floting reviewer tahap 2 oleh LPPM & Floting reviewer tahap 2 oleh smart system \\
\hline 7 & Review tahap 2 berupa presentasi tatap muka & $\begin{array}{l}\text { Review tahap } 2 \text { dilakukan oleh reviewer yang berbeda dengan } \\
\text { memberi skor dan alasan nilai tersebut tanpa presentasi tatap } \\
\text { muka }\end{array}$ \\
\hline 8 & Pengumuman review tahap 2 & $\begin{array}{l}\text { Proposal yang tereliminasi tahap } 2 \text { akan dikembalikan dengan } \\
\text { lembar penilaian dimana ada skor dan ada alasannya }\end{array}$ \\
\hline 9 & - & $\begin{array}{l}\text { Proposal yang lolos direview tahap } 3 \text { oleh smart system } \\
\text { berdasarkan kuota setiap skim }\end{array}$ \\
\hline 10 & - & Proposal yang menang diketahui oleh Ketua LPPM \\
\hline 11 & - & Pengumuman proposal yang lolos \\
\hline 12 & Upload kemajuan & $\begin{array}{l}\text { Upload kemajuan dengan lembar pengesahan memiliki proses } \\
\text { yang sama }\end{array}$ \\
\hline 13 & Verifikasi laporan oleh LPPM & Verifikasi laporan oleh smart system \\
\hline 14 & Monev oleh reviewer secara tatap muka & Monev dilakukan oleh smart system \\
\hline 15 & Upload laporan akhir & $\begin{array}{l}\text { Upload laporan akhir dengan system yang sama dalam } \\
\text { pengesahan }\end{array}$ \\
\hline 16 & Verifikasi laporan oleh LPPM & Verifikasi laporan oleh smart system \\
\hline 17 & Monev berupa bazar penelitian & Monev berupa bazar penelitian \\
\hline 19 & - & $\begin{array}{l}\text { Laporan akhir dikelompokkan pada } 5 \text { kelompok (1) } \\
\text { pengembangan ilmu pengetahuan; (2) pengembangan model; } \\
\text { (3) produk terapan; (4) inovasi produk; (5) Usaha }\end{array}$ \\
\hline 20 & - & $\begin{array}{l}\text { Sertiap divisi melakukan pengembangan, penyempurnaan } \\
\text { dan analisis hasil penelitian menjadi barang/jasa yang siap } \\
\text { pasarkan }\end{array}$ \\
\hline 21 & - & $\begin{array}{l}\text { Devisi usaha melakukan produksi dan memasarkan hasil } \\
\text { penelitian }\end{array}$ \\
\hline
\end{tabular}




\section{KESIMPULAN}

Dari hasil penelitian dapat disimpulkan bahwa sistem informasi simlitabmas yang dipergunakan sekarang perlu di perbaharui karena adanya ketidakpuasan dari pengusul yaitu pada (1) alur SIM yang selama ini dipakai; (2) standar reviewer; (3) transparansi penunjukkan; (4) objektifitas penilaian dan (5) hambatan pada alur proses kegiatan sehingga memerlukan perbaikan.

Smart system sebagai perbaharuan dari system yang ada memiliki kegiatan sebagai berikut: (1) Dekan/ Direktur dan Ketua LPPM tinggal membuka Siak pada plot pengesahan untuk menyatakan setuju atau tidak setuju; (2) Verifikasi proposal oleh smart system; (3) Floting reviewer dilakukan oleh smart system dari big data sesuai standar yang ditetapkan; (4) Review tahap 1: proposal dikirim via email tanpa nama dan surel dan penilaian disertai alasannya; (5) Proposal yang tereliminasi dikirim ulang dengan nilai dan alasan dari nilai tersebut; (6) Floting reviewer tahap 2 oleh smart system; (7) Review tahap 2 dilakukan oleh reviewer yang berbeda dengan memberi skor dan alasan nilai tersebut tanpa presentasi tatap muka; (8) Proposal yang tereliminasi tahap 2 akan dikembalikan dengan lembar penilaian dimana ada skor dan ada alasannya; (9) Proposal yang lolos direview tahap
3 oleh smart system berdasarkan kuota setiap skim; (10) Proposal yang menang diketahui oleh Ketua LPPM; (11) Pengumuman proposal yang lolos; (12) Upload kemajuan dengan lembar pengesahan memiliki proses yang sama; (13) Verifikasi laporan oleh smart system; (14) Monev dilakukan oleh smart system; (15) Upload laporan akhir dengan sistem yang sama dalam pengesahan; (16) Verifikasi laporan oleh smart system; (17) Monev berupa bazar penelitian; (18) Laporan akhir dikelompokkan pada 5 kelompok (1) pengembangan ilmu pengetahuan; (2) pengembangan model; (3) produk terapan; (4) inovasi produk; (5) Usaha; (19) Sertiap divisi melakukan pengembangan, penyempurnaan dan analisis hasil penelitian menjadi barang/jasa yang siap pasarkan; (20) Devisi usaha melakukan produksi dan memasarkan hasil penelitian.

Kelebihan SIM ini adalah (1) semuanya berbasis online sehingga akan efektif dan efisiensi waktu, biaya dan tempat; (2) transparansi dalam prosesnya; (3) memiliki standar baik pemilihan reviewer, penilaian, hasil penelitian; (4) hasil penelitian diolah menjadi produk yang dapat dipasarkan; (5) ada 5 devisi yang menangani hasil penelitian menjadi hasil usaha; (6) meningkatkan pendapatan universitas; (7) meningkatkan rangking, kepercayaan dan marwah universitas.

\section{DAFTAR RUJUKAN}

Al Ghofari, A. K., Anis, M., \& Nugroho, F. (2014). Perancangan Sistem Informasi Manajemen Pengeloaan Akademik Pada Program Studi Di Institusi Pendidikan Perguruan Tinggi X. Seminar Nasional IENACO, 1(1), 461-468.

Andayani, E. (2010). Konsep dan Kerangka Dasar Sistem Informasi Manajemen. In Sistem Informasi Manajeman (pp. 1-45). Bandung: Alfabeta.

Arif, M. S. (2012). Hubungan Antara Administrasi, Organisasi, dan Manajemen. In Organisasi dan Manajemen (pp. 1-56). Bandung: Alfabeta.

Aswati, S., Mulyani, N., Siagian, Y., \& Syah, A. Z. (2015). Peranan Sistem Informasi Dalam Perguruan Tinggi. Jurnal Teknologi dan Sistem Informasi, 1(2), 79-86.

Baihaqi. (2016). Pengawasan Sebagai Fungsi Manajemen Perpustakaan Dan Hubungannya Dengan Disiplin Pustakawan. LIBRIA, 8(1), 129-142.

Faqih, A., \& Informasi, S. (2005). Penerapan Konsep Perencanaan Sistem Informasi Akademik Perguruan Tinggi. Jurnal Administrasi Pendidikan, 1(1), 1-12.

Lubis, C. P. (2016). Implementasi Tri Dharma Perguruan Tinggi dalam Mendukung Disiplin Nasional. Sumatera.

Maryawan, I., Sumadi, \& Suntoro, I. (2013). Pengembangan Sistem Informasi Manajemen Berbasis Web (Studi kasus di Fakultas Teknik Universitas Lampung). Jurnal Manajemen, 1(1), 12.

Pangestika, W. (2018). Mengenal Sistem Informasi Manajemen dan Manfaatnya Bagi Perusahaan. 
Rokhayati, I. (2014). Perkembangan Teori Manajemen dari Scientific Manajemen hingga era moderen. Jurnal Ekonomi Dan Bisnis, 15(September), 1-20.

Sasongko, T. (2009). Pola Sistem Informasi Manajemen Bidang Akademik (Studi Multi-Kasus pada Tiga Perguruan Tinggi Swasta di Kota Malang). Universitas Negeri Malang.

Sudin. (2004). Pengabdian Kepada Masyarakat Bagi Perguruan Tinggi Agama Islam. Umal Aplikasi Llmu-Ilmu Agama, 5(2), 161-172.

Sugiyono. (2016). Metode Penelitian Kuantitatif Kualitatif dan R\&amp;D. Bandung: Alfabeta.

Susanto, H. M., Mantja, W., Bafadal, I., \& Sonhadji, A. (2017). Pengembangan Sistem Informasi Manajemen Pendidik dan Tenaga Kependidikan. Jurnal Pendidikan Humaniora, 6(3), 93-105. https://doi. org/10.26858/publikan.v6i3.2275

Taryono, En. (2018). Pengembangan Pt Menuju Era Revolusi Industri 4.0: Tantangan \& Harapan Melalui Peningkatan Perlindungan Kekayaan Intelektual (KI).

Wiguna, W. (2017). Adopsi Sistem Informasi Akademik Perguruan Tinggi BSI Bandung Berbasis TAM. Jurnal Informatika, 4(2), 189-197.

Wijaya, W. M. (2016). Strategic Information System Planning: Information Systems Required in Vocational School Models. Advances in Economics, Business and Management Research, volume 14. Atlantis Press. 